passages, which consists of the human dengue virus inoculated first into the rabbit and mouse, and then transfered to human body; the infected human virus produced severe infection in mouse. We have kept the mouse virus for a period of over four years by serial passages through mice.

Several investigations, were carried out with the mouse virus. For the purpose of protecting against dengue infection we prepared formol-vaccine from the mouse virus, and succeeded to keep human body resistant against an attack of dengue for about three months.

Acknowledgment is hereby made that these studies were made possible by the enthusiastic cooperation of Dr. M. Icho, Dr. Y. Yajima and Miss Y. Mitoma, who also offered themselves for' experimental infection, and by the technical assistance of Dr. M. Fukuda, Dr. K. Kimura and Dr. T. Ogushi.

\title{
REFERENCES
}

Blanc G. \& Caminopetros J.: Reseaches experimentales sur la dengue. Ann. Inst. pasteur, Vol. 44, No. 4, pp. 367-436, 1930. C. R. Acad. Sci. Vol. 187, No. 23, pp. 1081-1083, 1928.

Cleland J. B. \& Bradley B.: Further experiments in the etiology of dengue fever. J. Hyg. Vol. 18, No. 3, pp. 217-254, 1919.

Hoffmann J. M, Mertens W. K. \& Snijders E. P.: De overbrenging van de Javanische endemische dengue naar Amsterdam. Genesk Tiịdschr. Nederl-Indie. Nol. 72, No. 18, pp. 1195-1199, 1932.

Holt W. L.: Summary of dengue research. Southern Med. J. Vol. 16, No. 2, pp. 112-113, 1922.

Kawachi T.: Inoculation experiment of dengue virus into anterior chamber of animal eyes. Nippon Igaku, No. 3343, pp. 1340-1344, 1943.

Koizumi M., Yamaguchi M \& Tonomura K.: An epidemiological study of dengue fever. Taiwan Igakukai Nos $176 \&$ 177, pp. 369-392, 432-463, 1917.

Kuwashima K., Goto Z. \& Hara T. Experimental studies on dengue fever I. Nippon Igaku, No. 3325, pp. 531-534, 1943.

Ogata N. \& Yoshii M.: Studies on the isolation, reservation and properties of dengue virus. Nippon Igaku, No. 3338, pp! 1124-1128, 1943.

Taniguchi T.: Studies on dengue virus and immunity I. Special Report of Army Med. School. No. 632, 1943.

,Toda T., Nakagawa Y. \& Yanagi S.: Studies on dengue virus. 1II. Nippon Igaku No. 3333, pp. 919921, 1943.

Tsurumi S. \& Shin K.: Studies on dengue virus I. Nippon Igaku, No. 3341, pp. 1253-1255, 1943.

Yaoi H. \& Arakawa S.: Studies on dengue virus I. Nippon Igaku, No. 3319, pp. 244-247, 1943.

\section{ISOLATION OF PENICILLIN G N-ETHYLPIPERIDINE SALT AND SODIUM SALT AND THEIR STABILITY}

\author{
By Kenji MAEDA and HAmao UMEZAWA \\ National Institute of Health of Japan, Tokyo
}

Now it is an important problem for the Japanese penicillin production to produce stable and crystalline penicillin sodium salt. While we failed to crystallize penicillin as various amine salt, Kusaka and Kawashima (1) isolated crystalline penicillin G Nethylpiperidine salt, according to the method described by Seehan, Mader and Cram (2). 
Afterwards we also confirmed that penicillin G N-ethylpiperidine salt could be easily obtained by this method, and the penicillin sodium powder extracted from the modified Stone and Farrell's synthetic medium (surface culture) implanted with Q-176 strain contained penicillin $\mathrm{G}$ at about $60 \%$. Penicillin $\mathrm{G}$ sodium salt was also easily obtained from its $\mathrm{N}$-ethylpiperidine salt, and besides it was found that after the sodium salt obtained by freeze-drying had once dissolved in dry acetone, immediately it crystallized to the very stable salt. Present paper discusses the difference between crystalline penicillin $\mathrm{G}$ sodium obtained by freeze-drying and by the addition of dry acetone.

\section{ME'THOdS ANd MATERIALS}

(1) N-ethylpiperidine It was prepared according to the description by Bayer and Villiger (3) and Sawa, Inoue and Kitamura (4). The boiling point of N-Ethylpiperidine employed was $126.5-128.5^{\circ} \mathrm{C}$.

(2) Penicillin sodium salt The penicillin chiefly employed was produced by the surface culture with Q-176 strain and the modified Stone and Farrell's synthetic medium.

(3) Assay of potency Potency was measured by the cup method using penicillin sodium G crystal as the standard.

\section{RESULTS}

\section{Isolation of Penicillin G N-ethyipiperidine salt}

(1) Content of penicillin $G$ in the penicillin sodium powder produced by $Q-176$ strain in the synthetic medium. The content of penicillin $G$ in the sodium salt with the potency of $856 \mathrm{u} / \mathrm{mg}$ was tested by Sheehan, Mader, and Cram's method. This penicillin was produced in the synthetic medium (Lactose $3 \%$, glucose $0.4 \%$, acetic acid $0.5 \%, \mathrm{NH}_{4} \mathrm{NO}_{3}$ $0.5 \%, \mathrm{KH}_{2} \mathrm{PO}_{4} 0.2 \%, \mathrm{NaNO}_{3} 0.5 \%, \mathrm{MgSO}_{4} \cdot 7 \mathrm{H}_{2} \mathrm{O} \quad 0.05 \%,-\mathrm{FeSO}_{4} \cdot 7 \mathrm{H}_{2} \mathrm{O} \quad 0.02 \%, \mathrm{ZnSO}_{4} \cdot 7 \mathrm{H}_{2} \mathrm{O}$ $0.004 \%, \mathrm{CuSO}_{4} \cdot 5 \mathrm{H}_{2} \mathrm{O} 0.0005 \%$ phenylacetic acid $0.05 \%, \mathrm{pH} 6.1$ with $\mathrm{KOH}$ ) by Q-176 strain and extracted by solvent process, using butylacetate. As seen in Table 1 , its content of penicillin $\mathrm{G}$ was about $60 \%$.

Table 1. Content of penicillin $\mathrm{G}$ in the penicillin sodium powder $856 \mathrm{u} / \mathrm{mg}$ produced by Q-176 strain in the modified synthetic medium.

\begin{tabular}{c|c|c|}
\hline $\begin{array}{c}\text { Penicillin } \\
\text { Sodium Powder }\end{array}$ & $\begin{array}{c}\text { N-Ethylpiperidine } \\
\text { Salt }\end{array}$ & G content \\
\hline $200,000 \mathrm{u}$ & $93.4 \mathrm{mg}$ & $62.0 \%$ \\
\hline $200,000 \mathrm{u}$ & $86.0 \mathrm{mg}$ & $57.1 \%$ \\
\hline $200,000 \mathrm{u}$ & $102.2 \mathrm{mg}$ & $65.0 \%$ \\
\hline $200,000 \mathrm{u}$ & $87.0 \mathrm{mg}$ & $57.9 \%$ \\
\hline $200,000 \mathrm{u}$ & $78.8 \mathrm{mg}$ & $53.0 \%$ \\
\hline $300,000 \mathrm{u}$ & $145.6 \mathrm{mg}$ & $64.6 \%$ \\
\hline
\end{tabular}

(2) Effect of phenylacetic acid and ammonium sulfate on the content of penicillin G. As we already reported (5), ammonium nitrate can be substituted by ammonium 
sulfate without any loss of penicillin production. As the potencies of the penicillin sodium salt tested are below $800 \mathrm{u} / \mathrm{mg}$, the contents of penicillin 'G (Table 2) measured by Sheehan, Mader and Cram's method are not correct in the absolute value, but ma have the relative meaning. Content of $\mathrm{G}$ increased somewhat by substituting ammonium nitrate with ammonium sulfate.

It is noteworthy that any amount of penicillin $G$ could not be detected in the penicillin sodium extracted from the medium without phenylacetic acid. Phenylacetic acid seems to be an indispensable element for the production of penicillin $G$.

Table 2. Effect of phenylacetic acid, ammonium sulfate, and ammonium nitrate, added in the modified synthetic medium, on the content of penicillin G.

\begin{tabular}{|c|c|c|c|c|c|}
\hline $\begin{array}{l}\text { Composition of } \\
\text { medium }\end{array}$ & Penicillin (Total) & $\mathrm{u} / \mathrm{mg}$ & $\begin{array}{l}\text { N-ethylpiperidine } \\
\text { salt }\end{array}$ & G content & Average \\
\hline $\begin{array}{c}\quad\left(\mathrm{NH}_{4}\right)_{2} \mathrm{SO}_{4} 0.3 \% \\
\text { Phenylacetic acid } 0.2 \%\end{array}$ & $\begin{array}{l}238,000 \mathrm{u} \\
238,000 \mathrm{u}\end{array}$ & $\begin{array}{l}700 \\
700\end{array}$ & $\begin{array}{l}92.1 \mathrm{mg} \\
87.4 \mathrm{mg}\end{array}$ & $\begin{array}{l}51.5 \% \\
48.8 \%\end{array}$ & $50.2 \%$ \\
\hline $\begin{array}{c}\left(\mathrm{NH}_{4}\right)_{2} \mathrm{SO}_{4} 0.5 \% \\
\text { Phenylacetic acid } 0.1 \%\end{array}$ & $\begin{array}{l}183,500 \mathrm{u} \\
183,500 \mathrm{u}\end{array}$ & $\begin{array}{l}672 \\
672\end{array}$ & $\begin{array}{l}61.3 \mathrm{mg} \\
54.2 \mathrm{mg}\end{array}$ & $\begin{array}{l}44.5 \% \\
39.2 \%\end{array}$ & $41.9 \%$ \\
\hline $\begin{array}{c}\left(\mathrm{NH}_{4}\right)_{2} \mathrm{SO}_{4} 0.3 \% \\
\text { Phenylacetic } \\
\text { acid } 0.05 \%\end{array}$ & $\begin{array}{l}212,000 \mathrm{u} \\
212,000 \mathrm{u}\end{array}$ & $\begin{array}{l}399 \\
399\end{array}$ & $\begin{array}{l}6.90 \mathrm{mg} \\
73.2 \mathrm{mg}\end{array}$ & $\begin{array}{l}43.3 \% \\
45.9 \%\end{array}$ & $44.9 \%$ \\
\hline $\begin{array}{c}\left(\mathrm{NH}_{4}\right)_{2} \mathrm{SO}_{4} 0.3 \% \\
\text { Phenylacetic acid } 0 \%\end{array}$ & $\begin{array}{r}180,000 \mathrm{u} \\
180,000 \mathrm{u} \\
81,500 \mathrm{u}\end{array}$ & $\begin{array}{l}346 \\
346 \\
286\end{array}$ & $\begin{array}{l}0 \mathrm{mg} \\
0 \mathrm{mg} \\
0 \mathrm{mg}\end{array}$ & $\begin{array}{l}0 \% \\
0 \% \\
0 \%\end{array}$ & $0 \%$ \\
\hline $\begin{array}{c}\mathrm{NH}_{4} \mathrm{NO}_{3} 0.5 \% \\
\text { Pheylacetic acid } 0.1 \%\end{array}$ & $\begin{array}{l}219,000 \mathrm{u} \\
219,000 \mathrm{u}\end{array}$ & $\begin{array}{l}676 \\
676\end{array}$ & $\begin{array}{l}60.7 \mathrm{mg} \\
65.8 \mathrm{mg}\end{array}$ & $\begin{array}{l}36.9 \% \\
40.0 \%\end{array}$ & $385 \%$ \\
\hline
\end{tabular}

Basal medium: Lactose $4 \%$, glucose $0.4 \%$, acetic acid $0.5 \%, \mathrm{KH}_{2} \mathrm{PO}_{4} 0.2 \%, \mathrm{NaNO}_{3} 05 \%$, $\mathrm{MgSO}_{4} 7 \mathrm{H}_{2} \mathrm{O} \quad 0.05 \%, \mathrm{FeSO}_{4} .7 \mathrm{H}_{2} \mathrm{O} \quad 0.02 \%, \mathrm{ZnSO}_{4} 7 \mathrm{H}_{2} \mathrm{O} \quad 0.004 \%, \mathrm{CuSO}_{4} 5 \mathrm{H}_{2} \mathrm{O}$ $0.0005 \%$, pH 6.1 with $\mathrm{KOH}$.

(3) Content of $\mathrm{G}$ in the samples obtained by tank-culture (Medium; .Lactose 3\%, Polypeptone $2 \%, \mathrm{NaNO}_{3} 0.16 \%, \mathrm{KH}_{2} \mathrm{PO}_{4} 0.26 \%, \mathrm{MgSO}_{4} \cdot 7 \mathrm{H}_{2} \mathrm{O} 0.05 \%, \mathrm{ZnSO}_{4} \cdot 7 \mathrm{H}_{2} \mathrm{O} 0.0029 \%$, Phenylacetic acid $0.05 \%$, pH 5.6-5.8 with $\mathrm{KOH}$ ).

The content of $\mathrm{G}$ in the samples produced by tank-culture was alomost the same as that of thc surface culture, i.e., about $50 \%$.

(4) Stability and toxicity of crystalline penicillin G N-ethylpiperidine salt.

As it is necessary to know the stability of the crystalline N-Ethylpiperidine salt in order to convert it to sodium salt, the stability was tested. If it had been preserved at $0-10^{\circ} \mathrm{C}$, almost no loss of the activity could be found after one month.

The toxicity of penicillin G N-ethylperidine, salt was written in Table 3. Its minimal lethal dose for mice (about $10 \mathrm{~g}$ body weight) lies between $500-2,000 \mathrm{u}$, that is, this salt is much more toxic than sodium salt as the minimal lethal dose of the latter for mice are more than $16,000 \mathrm{u}$.

\section{Isolation of penicillin $G$ sodium salt}

If penicillin $\mathrm{G}$ N-ethylpiperidine salt is shaken with ether, chloroform, amylacetate, butylacetate, or ethylacetate and the necessary amount (calculated) of sodium bicarbonate 
Table 3. The toxicity of Penicillin G N-ethylpiperidine salt

\begin{tabular}{c|c|c|}
\hline $\begin{array}{c}\text { Amount of N-ethylpiperidine } \\
\text { salt injected to mice }\end{array}$ & Exp 1. \\
\cline { 2 - 3 } & $3 / 3$ & Mortality \\
\hline $4,000 \mathrm{u}$ & $3 / 3$ & $3 / 3$ \\
\hline $2,000 \mathrm{u}$ & $1 / 3$ & $2 / 3$ \\
\hline $1,000 \mathrm{u}$ & $0 / 3$ & $3 / 3$ \\
\hline $500 \mathrm{u}$ & $1 / 3$ & $0 / 3$ \\
\hline $250 \mathrm{u}$ & & \\
\hline
\end{tabular}

solution, the $\mathrm{pH}$ of the water layer becomes 6.5-7.0. In this reaction it seems that penicillin gose into the water layer as the sodium salt. On the other hand if penicillin $\mathrm{G}$ N-ethylpiperidine salt is dissolved in phosphate buffer and extracted with solvent at $\mathrm{pH}$ 2.5 and $0^{\circ} \mathrm{C}$, the results of the nitrogen determination in water layer indicates that almost all $\mathrm{N}$-ethylpiperidine is retained in the water layer. In order to remove N-ethylpiperidine completely, the penicillin $\mathrm{G}$ N-ethylperidine salt was first dissolved in phosphate buffer and extracted with amylacetate at $\mathrm{pH} 2.5$ and $0^{\circ} \mathrm{C}$. Then the amylacetate solution was titrated with sodium bicarbonate solution necessary amount of which was calculated on the basis of the amount of penicillin $G$ N-ethylpiperidine salt. The water solution of the penicillin G sodium was dried in frozen state, and the crystalline $G$ sodium salt was obtained,

Then we found very curious phenomenon. If dry acetone was added to this sodium salt after freeze-drying, sodium salt dissolved in acetone and immediately afterwards the fairly large crystals appeared. Both the crystals, obtainen by freeze-drying, and by addition of acetone, had almost the same potency as the standard penicillin $(1667 \mathrm{u} / \mathrm{mg})$. Besides the same phenomenon was observed if the crystals from acetone were dissolved in water, freeze dried, and again dissolved in dry acetone. Therefore this curious phenomenon is not due to impurities in the crystals.

It can be expected that this phenomenon may be due to the existence of either water molecules in the fine crystals after freeze-drying, or acetone molecules in large crystals from acetone. After the fine crystals had been dried at $60^{\circ} \mathrm{C}$ and $5 \mathrm{~mm}$ vacuum until the weight became constant, they were also soluble in dry acetone and crystals reappeared. Therefore, though there exist water molecules in fine crystals, they can not be removed by drying at $60^{\circ} \mathrm{C}$. The results of the nitrogen analysis $(7.35 \%$ in fine crystals after freeze-drying and $7.76 \%$ in crystals after the addition of 'acetone), however, indicated that one mol of crystals after freeze-drying contains one mol of water, as the nitrogen content of penicillin $\mathrm{G}$ sodium must be $7.86 \%$ and that with one mol of water is $7.48 \%$. The results of the elemental analysis deny the posspibillity that the crystals from acetone contains acetone molecule. Moreover it was found, as seen in Table 4, that the water contained in the crystals after freeze-drying could be removed by the drying at $100^{\circ} \mathrm{C}$, and the crystals became insoluble in dry acetone, though they lost about $20 \%$ activity during the drying. 
Table 4. Weight decrease, change of solubility in dry acetone observed, when penicillin $\mathrm{G}$ sodium after freeze-drying was heated at $60^{\circ} \mathrm{C}$ and $100^{\circ} \mathrm{C}$.

\begin{tabular}{|c|c|c|c|c|c|c|}
\hline \multirow{3}{*}{1} & Temp. & Hours & Weight decrease & Potency & $\begin{array}{l}\text { Potency } \\
\text { decrease }\end{array}$ & $\begin{array}{l}\text { Solubility } \\
\text { in acetone }\end{array}$ \\
\hline & $60^{\circ} \mathrm{C}$ & $\begin{array}{l}0 \\
3 \\
3\end{array}$ & $\begin{array}{l}- \\
2.1 \% \\
0 \%\end{array}$ & $\begin{array}{c}1658 \mathrm{u} / \mathrm{mg} \\
- \\
1585 \mathrm{u} / \mathrm{mg}\end{array}$ & $\begin{array}{l}- \\
- \\
0.4 \%\end{array}$ & $\begin{array}{l}\text { soluble } \\
\text { soluble } \\
\text { soluble }\end{array}$ \\
\hline & $100^{\circ} \mathrm{C}$ & $\begin{array}{l}3 \\
3 \\
3 \\
1\end{array}$ & $\begin{array}{r}0 \% \\
2.1 \% \\
6.1 \% \\
0 \%\end{array}$ & $\begin{array}{c}- \\
875 \mathrm{u} / \mathrm{mg} \\
-\end{array}$ & $\begin{array}{c}- \\
- \\
47.3 \% \\
-\end{array}$ & $\begin{array}{l}\text { soluble } \\
\text { soluble } \\
\text { insoluble } \\
\text { insoluble }\end{array}$ \\
\hline \multirow{2}{*}{2} & $60^{\circ} \mathrm{C}$ & $\begin{array}{l}0 \\
3\end{array}$ & $2.4 \%$ & $\begin{array}{l}1658 \mathrm{u} / \mathrm{mg} \\
1642 \mathrm{u} / \mathrm{mg}\end{array}$ & $-7 \%$ & $\begin{array}{l}\text { soluble } \\
\text { soluble }\end{array}$ \\
\hline & $100^{\circ} \mathrm{C}$ & $\begin{array}{l}3 \\
2 \\
3\end{array}$ & $\begin{array}{r}3.4 \% \\
0 \% \\
0 \%\end{array}$ & $\begin{array}{c}1380 \mathrm{u} / \mathrm{mg} \\
1282 \mathbf{u} / \mathrm{mg} \\
-\end{array}$ & $\begin{array}{c}16.5 \% \\
22.5 \% \\
-\end{array}$ & $\begin{array}{l}\text { insoluble } \\
\text { insoluble } \\
\text { insoluble }\end{array}$ \\
\hline
\end{tabular}

The valules in weight decrease are indicated as follows: for example in experiment 1 . weight decrease is $2.1 \%$ in first three hours, $0 \%$ in next three hours, $0 \%$ in third three hours at $100^{\circ} \mathrm{C}, 2.1 \%$ in fourth three hours, etc.

These two kinds of crystals are not only different from each other in the points of solubility in acetone and water of crystallization, but also in stability. As seen in Table

Table 5. The Stability of penicillin G sodium salts.

\begin{tabular}{|c|c|c|c|c|}
\hline \multirow{2}{*}{$\begin{array}{c}\text { Length of Time } \\
\text { stored at } \\
100^{\circ} \mathrm{C} \text { (hrs.) }\end{array}$} & & \multicolumn{2}{|c|}{ Crystals after freeze-drying } & \multirow{2}{*}{ Crystals from acetone } \\
\hline & & No. 1 & No. 2 & \\
\hline 0 & $\mathrm{u} / \mathrm{mg}$. & 1658 & 1585 & 1742 \\
\hline \multirow{2}{*}{10} & $\mathrm{u} / \mathrm{mg}$. & 1246 & 1525 & 1665 \\
\hline & $\begin{array}{l}\text { Potency } \\
\text { decrease }\end{array}$ & $25.2 \%$ & $3.6 \%$ & $0 \%$ \\
\hline \multirow{2}{*}{20} & $\mathrm{u} / \mathrm{mg}$ & - & 975 & 1770 \\
\hline & $\begin{array}{l}\text { Potency } \\
\text { decrease }\end{array}$ & - & $38.4 \%$ & $0 \%$ \\
\hline \multirow{2}{*}{40} & $\mathrm{u} / \mathrm{mg}$ & 627 & 760 & 1668 \\
\hline & $\begin{array}{l}\text { Potency } \\
\text { decrease }\end{array}$ & $62.3 \%$ & $52.1 \%$ & $=0 \%$ \\
\hline \multirow{2}{*}{80} & $\mathrm{u} / \mathrm{mg}$. & 464 & - & 1570 \\
\hline & $\begin{array}{l}\text { Potency } \\
\text { decrease }\end{array}$ & 72.9 & - & $5.6 \%$ \\
\hline \multirow{4}{*}{144} & $\mathrm{u} / \mathrm{mg}$. & - & - & 1605 \\
\hline & $\begin{array}{l}\text { Potency } \\
\text { decrease }\end{array}$ & - & - & $3.5 \%$ \\
\hline & $\mathrm{u} / \mathrm{mg}$. & - & - & 1615 \\
\hline & $\begin{array}{l}\text { Potency } \\
\text { decrease }\end{array}$ & - & - & $3.1 \%$ \\
\hline
\end{tabular}

Moisture content of crystals No. 1 is $2.42 \%$, No. $20.62 \%$ and that of crystals from acetone is $0.51 \%$. 
5 , the fine crystals obtained by freeze-drying lost $20-25 \%$ activity after 20 hours at $100^{\circ} \mathrm{C}$, but the crystals from acetome did not lose almost any activity after 6 days at $100^{\circ} \mathrm{C}$. The difference between potencies of the crystals from acetone before and after heating was within the range of the cup method error (5\%).

Already Yasuda (6) remarked that the penicillin sodium powder obtained by freezedrying was not so stable as the crystalline $G$ penicillin described in Article 21 of the American Food and Drug Administration, though its moisture content was under $1.5 \%$. Our experimental results indicate that the penicillin sodium obtained by freeze-drying, though it is crystalline, contains about one mol of water which can not be removed at $60^{\circ} \mathrm{C}$ and $5 \mathrm{~mm}$ vacuum, and it is not so stable as acetone insoluble crystals. It seems to be impossible to get stable penicillin sodium by freeze-drying process.

Intravenous injection of $10 \mathrm{mg}$ of both penicillin sodium crystals to mice (body weight $12 \mathrm{~g}$ ) did not induce any toxic reaction.

\section{DISCUSSION}

The production of crystaline penicillin $G$ sodium is at present an important problem in Japan. But it seems that this problem must be solved by changing the fermentation process than by the method of purification. If the $\mathrm{G}$ content increase's up to $90 \%$, it may be possible to get penicillin $G$ sodium crystal by the addition of dry acetone to the penicillin sodium powder obtained by freeze-drying. Indeed we observed that if dry acetone was added to the solution of commercial 'penicillin sodium powder with the potency of $800 \mathrm{u} / \mathrm{mg}$, white crystalline penicillin reappeared.

\section{SUMMARY}

(1) A confent of penicillin G sodium salt obtained by surface culture is about $60 \%$. It is increased by the addition of phenylacetic acid.

(2) Crystalline pencillin ' $\mathrm{G}$-ethylpiperidine and penicillin $\mathrm{G}$ sodium were isolated.

(3) Crystalline penicillin sodium obtained by freeze-drying lost $20-25 \%$ activity after 20 hours dit $100^{\circ} \mathrm{C}$. It was soluble in dry acetone and from this acetone solution stable penicillin $\mathrm{G}$ sodium appeared. One mol of crystalline penicillin $\mathrm{G}$ sodium after freezedrying seems to contain one mol of water.

Here we express our thanks to Dr. Ukita, a member of the Institute for Infectious Diesases and Dr. Kusaka in Takeda Pharmaceuetical Company for their kind advices, and also to Meiji Confectionary Company and Tachikawa Kogyo Company for the supply of material. This work was aided by a grant from Japan Penicillin Scientifie Association.

\section{REFERENCES}

1) Kusaka, Kawashima and Hitomi: Report at the Conference of Japan Penicillin Research Association, 19. Dec: 1947.

2) Sheehan, S., Mader, W.J., and Cram, D. J.: J. Am. Ch. Soc., 68, 2407, 1946. 
3) Bayer, Villiger: Ber. Deut. Chem. Ges., 34, 747, 1901.

4) Sawa, Iñüé, and Kitamura: Yakugakuzasshi (in Japanese), 63, 319, 1943.

5) Umezawa, H., Suzuki, S. and Takeuchi, T.: Studies on the surface culture for the penicillin production. Jap. Med. J., 1, 73, 1948.

6) Yasuda (Meiji factory): Private communication.

\title{
THEORETICAL STUDIES ON THE END POINT CURVE OF ROD.SHAPED PARTICLES IN ULTRAFILTRATION
}

\author{
By Hamao UMEZAWA and Nobuo TANAKA \\ National Institute of Health of Japan, Tokyo
}

The anomalous type of the end point curves in ultrafiltration of antibody is generally ascribed to the aggregation of the antibody molecules. But, on account of the rod-shape of antibody molecules, their end point curves must be much different from those of the spherical particles, even without the aggregation. In several reports $(1,2)$ concerning the structure of the antigen-antibody complex we inferred that antibodw molecules must be rod-shaped and attach to the antigens with their narrow edges. The present paper discusses the end point curve of rod-shaped particles and suggests that the anomalous type observed in the case of antibodies is not only due to the aggregation, but also to the shape of the antibody molecules.

Ferry (3) calculated statistically sieve constants in the case of spherical particles. His equation is in reasonable agreement with the experimental data of serum albumin, but a little different from those of foot and mouth disease virus and hemocyanin. This disagreement seems to be due to the shape of the particles. According to Neurath (4), serum albumin molecule is almost spherical, but foot and mouth disease virus (5) and hemocyanin (4) are rather rod-shaped.

We could calculate the sieve constants of rod-shaped particles in almost the same manner as Ferry (3). The theoretical curves agree with the experimental not only in their shape but also quantitatively, particularly with those experiments performed under ideal conditions.

I. Statistical evaluation of sieve constants of rod-shaped particles.

According to Mangold and Hofmann (6) the sieve constant (s) is defined as follows:

$$
S=\frac{C_{f}}{C_{s}}
$$

where $C_{f}$ is the instaneous concentration of a small sample of filtrate, and $C_{s}$ is the simultaneous concentration of the filtering solution.

The pore size of the membrane is expressed at first in terms of the diameter effectiv 